\title{
PENGARUH PENEMPATAN DAN PROMOSI JABATAN TERHADAP KINERJA KARYAWAN PADA PT. GRAMEDIA ASRI MEDIA KUPANG
}

\author{
LUKAS MA ${ }^{1)}$, TRI SURIS LESTARI ${ }^{2)}$ \\ ${ }^{1}$ SEKOLAH TINGGI ILMU EKONOMI OEMATHONIS \\ eks_kupang@yahoo.co.id \\ ${ }^{2}$ SEKOLAH TINGGI ILMU EKONOMI OEMATHONIS \\ trisuris@gmail.com
}

\begin{abstract}
Luke Ma. Thesis, 2017. The influence of placement and promotion of office on the performance of employess of PT. Gramedia Asri Media Kupang. Supervisor: Try Suris Lestari, S.Kom.,MM.

The problem in this research is placement data and promotion position at PT. Gramedia Asri Media Kupang is not in accordance with the standards set by Nasional Gramedia in KPI rules (key performance indicator), KPI/STD/GAM/02/2011 for 2012-2016. The formulation of the problem in this study is whether the placement and promotion of positions partially and simultaneously significant effect on employee performance at PT. Gramedia Asri Media Kupang in 2012-2016?

Based on the formulation of the problem, the purpose of this study is to determine the magnitude of the effect of placement and promotion of positions partially and simultaneouslly on the performance of employees at PT. Gramedia Asri Media Kupang.

The data needed in this study are primary data and secondary data obtained by way of distributing questionnaires, interviews, and study documentation. Data were analyzed statistically by using multiple linear regression technique which was processed with SPSS program version 20.00. The result of data analysis shows the influence of job placement and promotion on employee performance shown by coefficient of determination $\left(R^{2}\right)$ equal to $86,1 \%$ and the rest $13,9 \%$ influenced by other factors like work motivation, employee compesation, discipline level, leadership style, employee and other employee loyalty.

Based on the results of data analysis suggested to the management of PT. Gramedia Asri Media Kupang for the placement process is expected to pay attention to the elements of education level, working knowledge, work skilss, and work experience, as well as in the promotion phase of office to pay attention to the rules for its assesment given objectively and effectively through carring, credible, competen, competetive and customer delight. So it will be very useful to improve employee work performance.

Furthermore, to other researchers are expected to conduct further research to determine the performance of employees at PT. Gramedia Asri Media Kupang such as work motivation, employee compesation, discipline level, leadership style, employee work loyalty that can support the results of this study.

Keyword: Penempatan, Promosi Jabatan, Kinerja Karyawan.
\end{abstract}

\section{PENDAHULUAN}

\section{Latar Belakang Penelitian}

Manajemen-Sumber Daya Manusia memegang peranan yang sangat vital bagi terwujudnya tenaga kerja yang produktif, efektif dan efisien. Mengikuti defenisi Drucker
(2001:54), efektif di sini didefenisikan sebagai tenaga kerja yang mampu melakukan pekerjaan yang benar (Doing the right things). Setiap tenaga kerja mempunyai kemampuan memilih, menganalisa serta dapat melakukan apa yang seharusnya dilakukan dalam kaitannya dengan fungsinya dalam pencapaian tujuan perusahaan. 
Sedangkan efisien di sini dimaksudkan sebagai tenaga kerja yang mampu melakukan sesuatu dengan benar (Doing things right) artinya setelah tenaga kerja memahami dan mampu atas apa yang semestinya dilakukan, dan juga tenaga kerja dapat melakukannya dengan benar.

Berdasarkan konsep dari Drucker (2001:54), yakni "Doing the right things and doing things right." maka kunci pokok manajemen Sumber Daya Manusia adalah "how to find or get the best person, and how to maintenance it".Bagaimana mendapatkan orang yang tepat untuk pekerjaan yang tersedia dalam organisasi perusahaan kita, dan bagaimana kita dapat memelihara dan mempertahankannya. Untuk mendapatkan dan menempatkan orang yang tepat, maka keseluruhan prosesnya dinamakan proses manajemen-Sumber Daya Manusia dengan menerapkan fungsi manajemen-Sumber Daya Manusia, yang terdiri dari :

1. Human Resource Planning: Merancangkan kebutuhan dan pemanfaatan Sumber Daya Manusia bagi perusahaan.

2. Personnel Procurement: Mencari dan mendapatkan Sumber Daya Manusia termasuk di dalamnya rekrutmen, seleksi dan penempatan serta kontrak tenaga kerja.

3. Personnel Development: Mengembangkan Sumber Daya Manusia, termasuk di dalamnya program orientasi tenaga kerja, pendidikan dan pelatihan.

4. Personnel Maintenance: Memelihara Sumber Daya Manusia, termasuk di dalamnya pemberian penghargaan, insentif, jaminan kesehatan, dan keselamatan tenaga kerja, dll.

5. Personnel Utilization: Memanfaatkan dan mengoptimalkan Sumber DayaManusia termasuk di dalamnya promosi, demosi, transfer, dan separasi.

Selanjutnya dalam fungsi manajemen yang dimaksud dengan personnel procurement adalah mencari dan mendapatkan Sumber Daya Manusia termasuk proses rekruitmen, seleksi dan penempatan, serta kontrak tenaga kerja. Rivai, (2005:210), mengemukakan penempatan karyawan berarti mengalokasikan para karyawan pada posisi kerja tertentu hal ini khusus terjadi pada karyawan baru. Terhadap karyawan lama yang telah menduduki jabatan kerja termasuk sasaran fungsi penempatan karyawan dalam arti mempertahankan pada posisinya atau memindahkan pada posisi tertentu.

Menurut Hasibuan (2007:70), penempatan (placement) karyawan adalahtindak lanjut dari seleksi yaitu menempatkan calon karyawan yang diterima atau lulus seleksi pada jabatan atau pekerjaan yang membutuhkan dan sekaligus mendelegasikan wewenang (authority) kepada orang tersebut, dengan demikian calon karyawan tersebut dapat mengerjakan tugas-tugasnya dijabatan bersangkutan.

Menurut Siagian (2008:109), promosi ialah apabila seseorang pegawai dipindahkan dari satu pekerjaan lain yang tanggung jawabnya lebih besar tingkatannya dalam hierarki jabatan lebih tinggi dan penghasilannya lebih besar pula.

Menurut Keith Davis (2004:261), “A promotion accurs when an employee is moved from one job to another job that is higher in pay, responsibility, organization level".

(Promosi terjadi ketika seseorang karyawan dipindahkan dari satu jabatan ke jabatan lain, yang lebih tinggi imbalan, tanggung jawab dan tingkatannya dalam organisasi).

Hal ini memiliki nilai karena merupakan bukti pengakuan yang lain terhadap prestasi kerja yang dicapai oleh seseorang. Seseorang yang dipromosikan pada umumnya dianggap mempunyai prestasi yang baik dan juga ada beberapa pertimbangan lainnya yang menunjang kinerja secara pribadi dan kelompok.

Mangkunegara (2001:67), kinerja adalah hasil kerja secara kualitas dan kuantitas yang dicapai oleh seseorang pegawai/karyawan dalam melaksanakan tugasnya sesuai dengan tanggung jawab yang diberikan kepada pegawai/karyawan tersebut.

Menurut Teguh (2003:67), kinerja (perfomance) adalah hasil kerja yang dicapai oleh seseorang atau sekelompok orang dalam suatu organisasi, sesuai wewenang dan tanggung jawab masing-masing, dalam rangka mencapai tujuan organisasi bersangkutan secara 
legal, tidak melanggar hukum dan sesuai dengan moral maupun etika.

Kinerja merupakan penampilan hasil karya seseorang dalam bentuk kualitas ataupun kuantitas dalam suatu organisasi. Kinerja adalah tampilan individu maupun kelompok kerja dan penentuan tujuan setiap unit organisasi sebagai strategi dalam meningkatkan kinerja. Tujuan memberikan arah dan mempengaruhi bagaimana perilaku pekerja yang diharapkan organisasi dari setiap personal karyawan. Hal penting dalam kinerja adalah tujuan, ukuran, dan penilaian.

Berikut ini adalah data posisi jabatan yang saat ini ditempati dengan penempatan perekrutan oleh pihak manajemen khususnya oleh Human Resource Development (HRD) pada PT. Gremedia Asri Media Kupang selama tahun 2012 sampai 2016 yang tertera pada tabel 1.1 berikut ini: 
Tabel 1.1. Data sesuai dengan jabatan berdasarkan penempatan dari perekrutan disesuaikan dengan penempatan standar Gramedia Nasional di PT. Gramedia Asri Media Kupang

\begin{tabular}{|c|c|c|c|}
\hline NO & JABATAN & $\begin{array}{c}\text { PENEMPATAN } \\
\text { PEREKRUTAN } \\
\text { GRAMEDIA KUPANG }\end{array}$ & $\begin{array}{l}\text { PENEMPATAN STANDAR } \\
\text { GRAMEDIA NASIONAL }\end{array}$ \\
\hline 1 & Supervisior Penjualan & $\begin{array}{c}\text { Lulusan Sekolah Menengah } \\
\text { Atas (SMA) }\end{array}$ & $\begin{array}{c}\text { Lulusan S-1 Manajemen } \\
\text { Pemasaran }\end{array}$ \\
\hline 2 & $\begin{array}{l}\text { Cashier } \\
\text { Chief }\end{array}$ & $\begin{array}{c}\text { Lulusan S-1 } \\
\text { Ilmu Peternakan }\end{array}$ & $\begin{array}{c}\text { Lulusan S-1 } \\
\text { Ilmu Akuntansi }\end{array}$ \\
\hline 3 & $\begin{array}{l}\text { Human Resource } \\
\text { Development (HRD) }\end{array}$ & $\begin{array}{l}\text { Lulusan Sekolah Tinggi Ilmu } \\
\text { Manajemen Pemasaran }\end{array}$ & $\begin{array}{l}\text { Lulusan S-1 Psikologi, } \\
\text { Manajemen Sumber Daya } \\
\text { Manusia (SDM) }\end{array}$ \\
\hline 4 & Customer Service & $\begin{array}{c}\text { Lulusan Sekolah Menengah } \\
\text { Atas (SMA) }\end{array}$ & Lulusan S-1 Ilmu Komunikasi \\
\hline 5 & $\begin{array}{l}\text { EDP } \\
\text { Support }\end{array}$ & $\begin{array}{c}\text { Lulusan S-1 } \\
\text { Ilmu Sosial Politik }\end{array}$ & Lulusan S-1 Teknik Komputer \\
\hline
\end{tabular}

Sumber : PT. Gramedia Asri Media Kupang, 2017

Tabel 1.2. Penilaian Prestasi Kerja Karyawan Pada PT. Gramedia Asri Media Kupang Tahun 2016

\begin{tabular}{|c|c|c|c|c|}
\hline \multicolumn{4}{|l|}{ Unsur Penilaian } & Jumlah \\
\hline \multicolumn{4}{|c|}{ a. Sasaran Kerja Karyawan } & 2,1 \\
\hline \multirow{8}{*}{ b. Perilaku Kerja } & 1. Carring & 3 & Exceed Expectation & \\
\hline & 2. Credible & 2 & Need Improvement & \\
\hline & 3. Competent & 2 & Need Improvement & \\
\hline & 4. Competetive & 3 & Meet Expectation & \\
\hline & 5. Customer Delight & 5 & Outstanding & \\
\hline & Jumlah & 15 & & \\
\hline & Nilai Rata-rata & 3,0 & & \\
\hline & \multicolumn{2}{|l|}{ Nilai Perilaku Kerja } & $3,0 \times 30 \%$ & 0,9 \\
\hline \multicolumn{4}{|c|}{ Nilai Prestasi Kerja } & $\begin{array}{c}3,0 \\
\text { (Cukup) }\end{array}$ \\
\hline
\end{tabular}

Sumber : PT. Gramedia Asri Media Kupang, 2017

Berdasarkan data tabel 1.2 di atas menunjukkan bahwa penilaian perilaku kerja pada penilaian prestasi kerja karyawan pada PT. Gramedia Asri Media terdapat nilai perilaku kerja di bawah bobot nilai 3,0 yaitu pada unsur (perilaku kerja poin 2 credible dan poin 3 competent) sehingga berdampak pada jumlah nilai prestasi kerja, nilai perilaku kerja tersebut tidak sesuai dengan penilaian KPI (Key Perfomance Indicator) yang diatur dalam aturan tertulis pada manajemen PT. Gramedia Asri Media Kupang dengan nomor
KPI/STD/GAM/02/2011, yang menyatakan bahwa jika dalam penilaian hasilnya adalah 3,0 maka karyawan yang bersangkutan dinyatakan tidak mendapatkan peluang untuk dipromosikan jabatannya. Berdasarkan ketentuan standarnya, adalah dari rentang nilai 3,01 - 5,00 (angka mutu sebagai standar dalam roses promosi jabatan) merupakan penilaian rata-rata yang akan diproses ditiap tahun agar pihak manajemen terus melakukan evaluasi untuk dilakukan pengembangan dalam promosi jabatannya. Prasyarat untuk standar promosi 
dengan penilaian total 3,0 (cukup) dengan uraian penjelasannya adalah tidak mencapai penilaian standar untuk promosi jabatan di tahun 2016 karena rata-ratanya di bawah rentangan angka 3,01 - 5,00 (angka mutu sebagai standar dalam proses promosi jabatan).

Berdasarkan kondisi di atas, peneliti tertarik untuk melakukan penelitian dengan judul "Pengaruh Penempatan dan Promosi Jabatan terhadap Kinerja Kerja Karyawan pada PT. Gramedia Asri Media Kupang’’.

\section{Identifikasi Masalah}

Berdasarkan uraian pada latar belakang penelitian, maka masalah dalam penelitian dapat diidentifikasikan bahwa data penempatan perekrutan Gramedia Kupang dan promosi jabatan diduga belum sesuai dengan standar yang telah ditetapkan oleh Gramedia nasional dalam aturan KPI/STD/GAM/02/2011.

\section{Perumusan Masalah}

Berdasarkan identifikasi masalah di atas, maka dapat dirumuskan masalah sebagai berikut:

1. Apakah penempatan dan promosi jabatan secara parsial berpengaruh signifikan terhadap kinerja kerja karyawan pada PT. Gramedia Asri Media Kupang tahun 2016?

2. Apakah penempatan dan promosi jabatan secara simultan berpengaruh signifikan terhadap kinerja kerja karyawan pada PT. Gramedia Asri Media Kupang tahun 2016?

\section{Maksud dan Tujuan Penelitian Maksud Penelitian}

Penelitian ini bermaksud untuk mengumpulkan data dan informasi untuk mengetahui pengaruh penempatan dan promosi jabatan terhadap kinerja kerja karyawan pada PT. Gramedia Asri Media Kupang tahun 2016.

\section{Tujuan Penelitian}

Tujuan penelitian sesuai rumusan masalah diatas, adalah sebagai berikut :

1. Untuk mengetahui pengaruh penempatan dan promosi jabatan secara parsial terhadap kinerja kerja karyawan pada PT. Gramedia Asri Media Kupang tahun 2016.
2. Untuk mengetahui pengaruh penempatan dan promosi jabatan secara simultan terhadap kinerja kerja karyawan pada PT. Gramedia Asri Media Kupang tahun 2016.

\section{TINJAUAN PUSTAKA \\ Penempatan}

Penempatan kerja adalah penugasan kembali seorang karyawan kepada pekerjaan barunya, menurut Rivai(2005:170). Siagian (2002:168), berpendapat bahwa penempatan adalah akhir dari proses seleksi telah ditempuh dan lamaran seseorang diterima maka seseorang memperoleh status sebagai karyawan dan selanjutnya akan ditempatkan pada posisi tertentu.

\section{Promosi Jabatan}

Menurut Siagian(2009:169), Promosi jabatan adalah pemindahan pegawai/karyawan, dari satu jabatan/tempat kepada jabatan/tempat lain yang lebih tinggi serta diikuti oleh tugas, tanggung jawab, dan wewenang yang lebih tinggi dari jabatan yang diduduki sebelumnya. Dan pada umumnya promosi yang diikuti dengan peningkatan income serta fasilitas yang lain.

\section{Pengertian Kinerja Kerja}

Berdasarkan defenisi para ahli dapat dikatakan kinerja adalah hasil kerja yang dicapai oleh seseorang baik secara kualitas maupun secara kuantitas sesuai wewenang dan tanggung jawabnya berdasarkan kecapakan, pengalaman, kesungguhan dan waktu.

\section{Tujuan dan Kegunaan Penilaian Kinerja Kerja}

Menurut Soelaiman (2007:285), tujuan penilaian kinerja adalah sebagai berikut :

1. Untuk memberikan dasar bagi rencana dan pelaksanaan pemberian penghargaan bagi karyawan atas kinerja pada periode waktu sebelumnya.

2. Untuk memotivasi agar pada periode waktu yang akan datang kinerja seorang karyawan dapat ditingkatkan.

3. Sebagai dasar informasi dan data untuk pengambilan keputusan menaikkan atau menurunkan gaji. 
4. Sebagai dasar informasi dan dasar untuk pengambilan keputusan mengenai status karyawan, pemutusan hubungan kerja (PHK), demosi , dan lain sebagainya.

5. Sebagai dasar informasi dan data untuk kebijakan promosi.

6. Sebagai dasar informasi dan data untuk untuk penempatan-penempatan (positioning)karyawan pada tugas-tugas tertentu.

7. Sebagai dasar informasi dan data untuk memperkirakan kebutuhan akan pelatihan bagi karyawan dalam organisasi.

8. Sebagai dasar informasi dan data memperkirakan kebutuhan akan pelatihan bagi karyawan dalam berorganisasi.

9. Sebagai dasar informasi dan data untuk mengevaluasi program latihan, efektivitas jadwal kerja, metode kerja, struktur organisasi, mekanisme pengawasan dan monitoring, kondisi kerja, peralatanperalatan kerja, dan kemampuan kerja karyawan.

10. Sebagai dasar informasi dan data untuk mengetahui aspek-aspek kompetensi yang masih perlu ditingkatkan oleh karyawan.

11. Sebagai dasar informasi dan data untuk memperbaiki dan mengembangkan deskripsi pekerjaan (job description) maupun desain pekerjaan (job design).

12. Hasil penilaian kinerja (performance apparaisal) karyawan dapat memperbaiki keputusan-keputusan personalia dan memberikan umpan balik kepada karyawan tentang pelaksanaan kerja mereka.

\section{Unsur-unsur Penilaian Kinerja Kerja}

Teguh (2003:30), mengemukakan empat

(4) unsur yang harus dipenuhi oleh karyawan untuk menentukan bahwa seorang karyawan memiliki kinerja kerja yang baik, yaitu:

1. Kualitas yaitu tingkat dimana hasil aktivitas yang dilakukan mendekati sempurna dalam menyesuaikan beberapa cara ideal dari penampilan aktivitas ataupun memenuhi tujuan-tujuan yang diharapkan dari suatu aktivitas.

2. Kuantitas yaitu jumlah yang dihasilkan dinyatakan dalam istilah-istilah seperti dolar, jumlah unit, jumlah siklus aktivitas yang diselesaikan.

3. Ketepatan waktu yaitu tingkat suatu aktivitas diselesaikan pada waktu awal yang diinginkan, dilihat dari sudut koordinasi dengan hasil output serta memaksimalkan waktu yang tersedia untuk aktivitas lain.

4. Efektivitas yaitu tingkat penggunaan sumber daya organisasi (tenaga, uang, teknologi, bahan baku) dimaksimalkan dengan maksud menaikkan keuntungan atau mengurangi kerugian dan setiap unit atau instansi dalam penggunaan sumber daya.

5. Kemandirian yaitu berhubungan dengan tingkat kemandirian yang dimiliki oleh karyawan dalam melaksanakan tugas dan tanggung jawabnya.

\section{Pengaruh Penempatan dan Promosi Jabatan terhadap Kinerja Kerja Karyawan}

\section{Pengaruh Penempatan Karyawan Terhadap Kinerja Kerja Karyawan}

Faktor-faktor yang perlu dipertimbangkan dalam penempatan karyawan, menurut Schuler dan Jackson (2007:276), mengemukakan faktor-faktornya adalah keterampilan, kemampuan, preferensi dan kepribadian karyawan. Wahyudi (2002:32), mengemukakan bahwa dalam melakukan penempatan karyawan hendaklah mempertimbangkan faktor-faktor sebagai berikut : 1) Pendidikan yang seharusnya. 2) Pendidikan alternatif. 3) Pengetahuan kerja. 4) Keterampilan kerja. 5) Pengalaman kerja.

\section{Pengaruh Promosi Jabatan terhadap Kinerja Kerja Karyawan}

Pengaruh promosi jabatan terhadap kinerja kerja karyawan dapat dilihat pada pendapat Nasution (2000.81), promosi adalah proses bergerak maju dan meningkat dalam suatu jabatan yang di dudukinya. Menurut Siagian (2009.169), promosi adalah perpindahan karyawan dari suatu pekerjaan ke pekerjaan lain yang tanggung jawabnya lebih besar, tingkatan hirarki jabatannya lebih tinggi dan penghasilannya pun lebih besar pula. Dari peryataan di atas maka, dapat disimpulkan bahwa promosi jabatan ditandai dengan adanya 
perubahan posisi ke tingkat yang lebih tinggi. Adanya perubahan tersebut menimbulkan tanggung jawab, hak, status dan wewenang yang meningkat, serta statusnya semakin besar dan pendapatannya juga disertai peningkatan fasilitas lainnya.

\section{Pengaruh Penempatan Dan Promosi Jabatan Terhadap Kinerja Kerja Karyawan}

Apabila seorang karyawan memperoleh penempatan yang tepat dan dipromosikan jabatan yang sesuai maka pekerjaan dan jabatan juga kompensasi yang akan diterima secara otomatis akan meningkat. Hal ini akan dapat menimbulkan kepuasan kerja yang lebih dari sebelumnya dan kinerja karyawan akan semakin baik (Siagian, 2009:140 ).

\section{Penelitian Terdahulu}

Untuk mendukung penelitian tentang "Pengaruh Penempatan dan Promosi Jabatan Terhadap Kinerja Kerja Karyawan pada PT. Gramedia Asri Media Kupang', perlu dikemukakan penelitian sejenis diantaranya :

1. Wantur (skripsi:2009), "Pengaruh Program Kesejahteraan terhadap Kinerja Karyawan pada pusat Koperasi Unit Desa (PUSKUD) NTT". Tujuan penelitian tersebut untuk mengetahui pengaruh program kesejahteraan terhadap kinerja karyawan pada PUSKUD NTT tahun 2008.

Program kesejahteraan yang dilakukan Wantur, menggunakan indikator menurut Hasibuan (2007:188), yaitu keadilan dan kelayakan. Indikator kinerja karyawan yang digunkan Wantur adalah teori menurut Gomes (2003:134), yaitu quantity of work, quality of work, job knowledge, creativiness, cooperation, dependability, initiative dan personal qualities. Jenispenelitian bersifat asosiatif. Jenis data yang digunakan menurut sifatnya adalah meliputi data kuantitatif dan data kualitatif, sedangkan jenis data menurut sumbernya adalah data primer dan data sekunder. Teknik pengumpulan data menggunkan kuesioner, studi dokumentasi dan wawancara. Teknik analisis yang digunakan adalah analisis statistik dengan menggunakan analisis regresi linear sederhana.
Hasil penelitian Wantur menunjukkan bahwa besarnya pengaruh program kesejateraan terhadap kinerja kerja karyawan PUSKUD NTT adalah sebesar $1,4 \%$ yang dalam klasifikasi Guilford termasuk kategori sangat rendah. Hal ini berarti kinerja karyawan PUSKUD NTT dalam tahun 2004-2008 sebesar 1,4\% dipengaruhi oleh program kesejahteraan, sedangkan sisanya sebesar 98,6\% dipengaruhi oleh faktor lain yang tidak diteliti seperti motivasi, kompensasi, dan lain-lain.

2. Rosadalima (skripsi:2015), dengan judul "Pengaruh Disiplin terhadap Kinerja Kerja Pegawai pada kantor Pertanahan Kota Kupang". Tujuan penelitian ini untuk mengetahui seberapa besar pengaruh antara disiplin terhadap kinerja kerja pegawai pada kantor Pertahanan kota Kupang. Teknik pengumpulan data yang digunakan melalui kuesioner, wawancara, dan dokumentasi. Indikator disiplin yang digunakan adalah teori Tu'u (2004:33), yaitu mentaati peraturan, kesadaran diri, sebagai alat pendidikan dan hukuman. Indikator Kinerja kerja yang digunakan adalah teori Micoriza (2003:30), yaitu kualitas, kuantitas, ketepatan waktu, efektivitas, dan kemandirian. Jenis penelitian bersifat asosiatif. Jenis data yang digunakan adalah data menurut sifatnya yaitu data kuantitatif dan data kualitatif sedangkan jenis data menurut sumber yang digunakan adalah data primer dan data sekunder. Teknik analisis yang digunakan adalah analisis statistik dengan menggunakan analisis regresi linear sederhana.Hasil analisis menunjukkan bahwa nilai koefisien determinasi $\left(\mathrm{R}^{2}\right)$ adalah sebesar 0,538 Dengan demikian dapat diartikan bahwa variabel bebas yaituvariabel Disiplin (X) mempunyai sumbangan sebesar 53,8 \% terhadap Kinerja kerja pegawai (Y) di kantor Pertahanan kota Kupang.

Berpedoman pada penelitian Wantur (Skripsi:2009), dan Rosadalima (Skripsi:2015) peneliti melakukan penelitian dengan judul "Pengaruh Penempatan dan Promosi Jabatan 
Terhadap Kinerja Kerja Karyawan pada PT. Gramedia Asri Media Kupang”. Tujuan penelitian ini untuk mengetahui apakah ada pengaruh pengaruh secara parsial dan simultan antara penempatan dan promosi jabatan terhadap kinerja kerja karyawan pada PT. Gramedia Asri Media Kupang.

\section{Kerangka Pemikiran}

Berdasarkan pada telaah pustaka sebelumnya, kerangka pemikiran yang diajukan untuk penelitian ini adalah seperti pada gambar 2.1 .

Gambar 2.1. Skema Kerangka Pemikiran

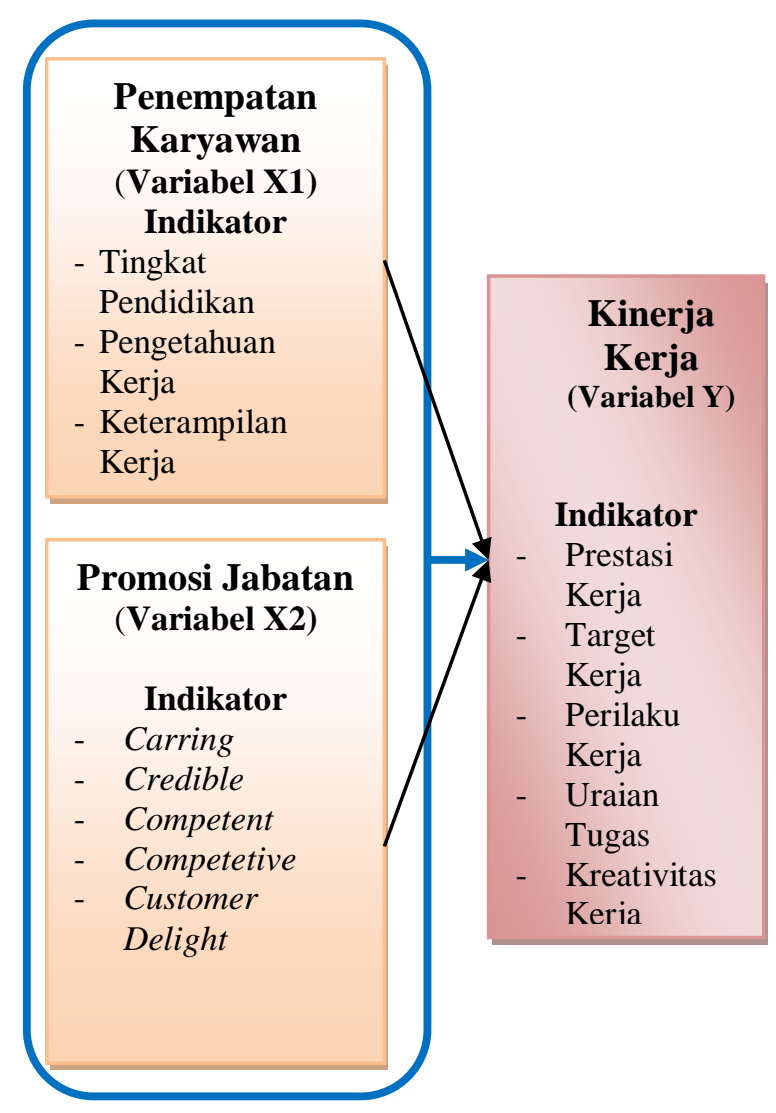

Keterangan :

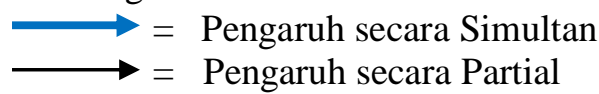

\section{Hipotesis}

Berdasarkan kerangka pemikiran di atas maka hipotesis atau jawaban sementara dari penelitian ini meliputi:
1. penempatan karyawan dan promosi jabatan berpengaruh secara parsial terhadap kinerja kerja karyawan.

2. Penempatan Karyawan dan Promosi Jabatan berpengaruh secara simultan terhadap kinerja kerja karyawan.

\section{METODE PENELITIAN \\ Populasi}

Menurut Sudjana (2009:118), populasi adalah totalitas nilai hasil penghitungan, pengukuran kuantitaif maupun kualitatif dari karakteristik tertentu mengenai sekumpulan obyek yang lengkap dan jelas yang ingindipelajari sifat-sifatnya. Pada penelitian ini, populasi penelitian adalah karyawan pada PT. Gramedia Asri Media Kupang yang keseluruhannya berjumlah 31 0rang.

\section{Uji Validitas dan Reliabilitas Instrumen Uji Validitas}

Menurut Siagian dan Sugiarto (2002:271), suatu instrumen dikatakan valid apabila mampu mengukur apa yang hendak diukur serta dapat mengungkapkan data dari variabel-variabel yang akan diteliti secara tepat. Untuk menguji validitas alat ukur, maka terlebih dahulu dicari harga korelasi antara bagian-bagian dari alat ukur secara keseluruhan dengan cara mengkorelasikan setiap butir alat ukur dengan skor total yang merupakan jumlah tiap skor butir dengan menggunakan rumus Pearson Product Moment.

Kaidah keputusannya adalah:

Jika nilai sig < 0,05 dinyatakan valid.

Jika nilai sig $>0,05$ dinyatakan tidak valid.

\section{Uji Reliabilitas}

Uji reliabilitas atau uji kehandalan adalah menguji kepercayaan suatu alat ukur dalam penelitian ini. Menurut Mustafa (2009:224), reliabilitas adalah ukuran yang menunjukkan seberapa tinggi suatu instrumen dapat dipercaya atau dapat diandalkan, artinya reliabilitas menyangkut ketepatan (dalam pengertian konsisten) alat ukur.

Kaidah keputusannya adalah:

Dikatakan reliabel, jika nilai Cronbach's Alpha> 0,6. 


\section{Teknik Analisis Data}

Berdasarkan rumusan masalah dan hipotesis yang disampaikan dalam penelitian ini, maka teknik analisisnya meliputi :

\section{Korelasi}

a. Rumus

$$
\begin{aligned}
& \mathrm{r}=\frac{n \sum x i y i-\left(\sum x i\right)\left(\sum y i\right)}{\sqrt{\left\{n \sum x^{2}-\left(\sum x i\right)^{2}\right\}\left\{n \sum y i^{2}-\left(\sum y i\right)^{2}\right\}}} \\
& \text { (Sugiyono 2015:184) }
\end{aligned}
$$

b. Kaidah keputusan :

1) jika nilai signifikan $<0,05$ maka terdapat korelasi, sebaliknya jika nilai signifikan >0,05 maka tidak terdapat korelasi.

2) Jika nilai koefisien korelasi semakin mendekati 1 atau - 1, maka hubungan antara dua variabel akan semakin erat.

\section{Regresi linear berganda}

a. Rumus

$$
Y^{\prime}=a+b 1 X_{1}+b 2 X_{2}+\ldots \ldots . .+b n X n
$$

b. Kaidah keputusan :

1) Membandingkan nilai signifikan dengan nilai angka $=0,05$.

2) Membandingkan nilai t hitung dengan nilai t tabel.

\section{Pengujian Hipotesis}

Untuk melakukan pengujian hipotesis dalam penelitian ini ada 2 uji pengaruh yang akan dilakukan meliputi:

\section{a. Secara Parsial (Uji t)}

Uji hipotesis secara parsial bertujuan untuk mengetahui apakah semua variabel bebas secara sendiri-sendiri mempunyai pengaruh yang signifikan atau tidak terhadap variabel terikat.

Ho: $b_{i}=0$, artinya variabel bebas yakni penempatan $\left(\mathrm{X}_{1}\right)$ atau promosi jabatan $\left(\mathrm{X}_{2}\right)$ tidak mempunyai pengaruh yang signifikan terhadap kinerja karyawan (Y).

Ha: $b_{i} \neq 0$, artinya variabel bebas yakni penempatan $\left(\mathrm{X}_{1}\right)$ dan promosi jabatan $\left(\mathrm{X}_{2}\right)$ secara parsial mempunyai pengaruh yang signifikan terhadap variabel terikat.
Kaidah pengambilan keputusannya:

Jika nilai signifikan lebih besar dari nilai ( $\alpha$ ) yang ditetapkan 5\%, maka keputusannya menerima hipotesis nol (H0) dan menolak hipotesis alternatif $(\mathrm{Ha})$, artinya secara parsial variabel penempatan atau promosi jabatan mempunyai pengaruh yang tidak signifikan terhadap variabel kinerja karyawan.

Jika nilai signifikan lebih kecil dari $(\alpha)$ yang ditentukan 5\%, maka keputusannya adalah menolak hipotesis nol (H0) dan menerima hipotesis alternatif (Ha), artinya secara parsial variabel penempatan dan promosi jabatan mempunyai pengaruh yang signifikan terhadap variabel kinerja karyawan.

\section{b. Secara Simultan (Uji F)}

Uji hipotesis secara simultan bertujuan untuk mengetahui apakah kedua variabel bebas secara bersama mempunyai pengaruh yang signifikan atau tidak terhadap variabel terikat. Menurut Sugiyono (2012:235) untuk melakukan uji pengaruh secara simultan dengan formula berikut;

$$
\mathrm{F}_{\mathrm{h}}=\frac{R^{2} / k}{\left(1-R^{2}\right) /(n-k-1)}
$$

Ho: $b_{i}=0$, artinya variabel penempatan $\left(\mathrm{X}_{1}\right)$ dan promosi jabatan $\left(\mathrm{X}_{2}\right)$ tidak mempunyai pengaruh yang signifikan terhadap variabel kinerja kerja karyawan (Y).

Ha; minimal salah satu $b_{i} \neq 0$, artinya penempatan $\left(\mathrm{X}_{1}\right)$ dan promosi jabatan $\left(\mathrm{X}_{2}\right)$ secara simultan mempunyai pengaruh yang signifikan terhadap variabelkinerja kerja karyawan.

\section{Koefisien Determinasi $\left(\mathbf{R}^{\mathbf{2}}\right)$}

Menurut Kuncoro (2003:220), koefisien determinasi $\left(\mathrm{R}^{2}\right)$ dimaksudkan untuk mengetahui kontribusi dari variabel bebas terhadap variabel terikat. 
Nilai Koefisien Determinasi $\left(\mathrm{R}^{2}\right)$ yang mendekati nol berarti kemampuan variabel bebas dalam menjelaskan variabel terikat sangat rendah. Sebaliknya nilai Koefisien Determinasi $\left(\mathrm{R}^{2}\right)$ yang mendekati satu berarti variabel bebas memberikan hampir semua informasi yang dibutuhkan untuk memprediksi variabel terikat.

Kaidah pengambilan keputusan:

a. Jika nilai signifikan lebih besar dari nilai $(\alpha)$ yang ditetapkan 5\%, maka keputusannya menerima hipotesis nol (H0) dan menolak hipotesis alternatif (Ha), artinya secara parsial variabel penempatan dan promosi jabatan mempunyai pengaruh yang tidak signifikan terhadap variable kinerja karyawan.

b. Jika nilai signifikan lebih kecil dari $(\alpha)$ yang ditentukan 5\%, maka keputusannya adalah menolak hipotesis nol (H0) dan menerima hipotesis alternatif (Ha), artinya secara parsial variabel penempatan dan promosi jabatan mempunyai pengaruh yang signifikan terhadap variabel kinerja kerja karyawan.

\section{HASIL PENELITIAN DAN PEMBAHASAN}

\section{Karateristik Responden}

Sebelum disajikan data hasil penelitian setiap variabel yang diuji dalam penelitian ini, terlebih dahulu perlu dideskripsikan karateristik responden secara singkat. Karateristik responden dimaksud untuk menguraikan atau memberi gambaran mengenai identitas responden yang dapat dikelompokan menjadi beberapa kelompok yaitu: umur, jenis kelamin dan tingkat pendidikan.

\section{Hasil Uji Validitas dan Reliabilitas}

Item-item pertanyaan yang ditujukan kepada responden dengan menggunakan bentuk kuisioner dikatakan valid dan reliable jika ada korelasi dengan skor total. Pengujian validitas dan Reliabilitas item-item pertanyaan menggunakan bantuan software IBM SPSS Statistik 20 dan diperoleh hasil bahwa nilai signifikan di bawah angka 0,05 dan 1 nilai Cronbach's Alpha lebih besar dari 0,6 sehingga dapat disimpulkan bahwa seluruh indikator item-item adalah valid dan reliabel.

\section{Penempatan}

Melalui proses perekrutan, setiap calon karyawan yang telah ditentukan untuk bergabung di toko buku Gramedia Kupang setelah melewati beberapa ujian yang menjadi syarat utamanya. Atas hasil ujian tersebut yang akan berpengaruh pada tahap penempatan yakni sesuai dengan posisi yang dibutuhkan berdasarkan pencapaian hasil tes karyawan yang bersangkutan. Setiap karyawan, akan ditempatkan pada posisi jabatan yang akan dievaluasi secara berkala selama 3 bulan dalam masa traning. Selama tahun 2016, karyawan yang telah direkrut dan ditempatkan pada posisinya sebanyak 22 orang, dengan jabatan sebagai cashier, store associate counter, store associate book, customer service dan ware house.

\section{Promosi Jabatan}

Dalam standar operasional (SOP) yang dijalankan di toko buku Gramedia Kupang pada tahun 2012-2016, ada beberapa jabatan yang telah diisi/ditempati berdasarkan promosi yang dilakukan oleh manajemen secara internal. Atas ketentuan promosi jabatan tersebut maka standar penilaian dalam promosi yang meliputi carring, credible, competent, competetive, dan customer delightmenjadi tolak ukur.

Selama kurun waktu 2012-2016, promosi jabatan yang telah dilakukan adalah store associate menjadi cashier sebanyak 3 orang, store associate menjadi customer service sebanyak 1 orang, store associate counter menjadi store associate book sebanyak 4 orang dan cashier menjadi accounting sebanyak 1 orang. 
Kondisi Kinerja Kerja Karyawan PT. Gramedia Asri Media Kupang pada tahun 2016

Setiap karyawan sudah memiliki standar penilaian dari perusahaan sejak tahap penempatan awal dan akan dilakukan proses penilaian secara berkala dalam masa traning selama kurun waktu 3 bulan. Dalam perkembangan kinerja masing-masing karyawan akan dilihat dari segi prestasi kerja, target kerja, perilaku kerja, uraian tugas dan kreativitas kerja.

Tabel 4.2. Standar Penilaian Kinerja Kerja Pada PT. Gramedia Asri Media Kupang Tahun

\begin{tabular}{|c|c|l|}
\multicolumn{3}{c}{} \\
NO & $\begin{array}{c}\text { BOBOT } \\
\text { PENILAIAN }\end{array}$ & \multicolumn{1}{|c|}{ KETERANGAN } \\
\hline 1 & 1 & Excited Point \\
\hline 2 & 2 & Need Improvement \\
\hline 3 & 3 & Meet Expectation \\
\hline 4 & 4 & Exceced Expectation \\
\hline 5 & 5 & Outstanding \\
\hline
\end{tabular}

Sumber : PT. Gramedia Asri Media Kupang

\section{Pembahasan}

Berdasarkan teknik analisis dalam penelitian ini setelah diproses dengan program SPSS versi 20.00 diperoleh hasilnya sebagai berikut :

\section{Analisis Korelasi}

Untuk mengetahui hubungan penempatan $\left(\mathrm{X}_{1}\right)$ dan promosi jabatan $\left(\mathrm{X}_{2}\right)$ terhadap kinerja kerja karyawan (Y), digunakan analisis korelasi dan diperoleh hasilnya adalah sebagai berikut : Nilai pearson correlation sebesar 0,850 dengan Sig. (2-tailed) sebesar 0,000 atau lebih kecil dari 0,05 sehingga diputuskan penempatan dan kinerja karyawan berhubungan signifikan.

Nilai pearson correlation sebesar 0,928 dengan Sig. (2-tailed) sebesar 0,000 atau lebih kecil dari 0,05 sehingga diputuskan promosi jabatan dan kinerja karyawan berhubungan signifikan.

\section{Analisis Regresi Linear Berganda}

Digunakan untuk menganalisa apakah ada pengaruh yang signifikan dari variabel bebas penempatan dan promosi jabatan terhadap variabel terikat kinerja kerja karyawan. Hasil analisis terlihat pada tabel 4.12 .

Untuk membaca hasil analisis data yang telah dilakukan sebelumnya, peneliti membaca hasil dengan menggunakan standardized coefficient. Standarized variables adalah variabel-variabel yang datanya telah distandarisasi dengan standar deviasi masing-masing variabel, baik variabel dependent maupun variabel independentnya. Jadi output regresi yang dihasilkan software SPSS, beta coefficient/ standardized coefficient, dihasilkan melalui proses tersebut. Dapat dilakukan penghitungan regresi dengan standardized variabel adalah untuk mendapatkan koefisien yang memiliki basis unit yang sama, sehingga (dalam multiple regresion) dapat membandingkan secara langsung antar variabel independent.dalam pengaruhnya masing-masing terhadap variabel dependent. Variabel dependent mana yang berpengaruh lebih besar terhadap variabel independent dapat dilihat dari besar kecilnya masing-masing koefisien (beta).

Tabel 4.12. Hasil uji regresi liniear berganda variabel penempatan dan promosi jabatan terhadap variabel kinerja

\begin{tabular}{|c|l|r|r|r|}
\hline \multicolumn{2}{|c|}{ kerja karyawan } \\
\multicolumn{2}{|c|}{ Model } & \multicolumn{2}{l|}{$\begin{array}{l}\text { Unstandardized } \\
\text { Coefficients }\end{array}$} & $\begin{array}{l}\text { Standar- } \\
\text { dized } \\
\text { Coeffici- } \\
\text { ents }\end{array}$ \\
\cline { 3 - 5 } \multicolumn{2}{c|}{} & \multicolumn{1}{|c|}{ B } & Std.Error & \multicolumn{1}{c|}{ Beta } \\
\hline \multirow{3}{*}{1} & (Constant) & 1,216 & 4,091 &, 301 \\
\cline { 2 - 5 } & X1 &, 343 &, 116 &, 688 \\
\cline { 2 - 5 } & X2 &, 852 &, 127 & \\
\hline
\end{tabular}

a. Dependent Variabel: Y

Berdasarkan Tabel 4.12 di atas diperoleh suatu persamaan regresi adalah sebagai berikut:

$$
Y=1,216+0,852 X_{1}+0,343 X_{2}
$$

Keterangan:

$\mathrm{Y}=$ Kinerja kerja karyawan

$\mathrm{X}_{1}=$ Penempatan

$\mathrm{X}_{2}=$ Promosi jabatan 


\section{Pengujian Hipotesis}

\section{a. Uji hipotesis secara Parsial (Uji t)}

Uji koefisien regresi secara parsial atau uji t digunakan untuk, mengetahui pengaruh secara parsial variabel bebas penempatan (X1), dan promosi jabatan (X2) terhadap variabel terikat kinerja kerja karyawan (Y). Hasil uji regresi secara parsial dari variabel bebas terhadap kinerja kerja karyawan dapat dilihat pada tabel 4.14:

Tabel 4.14. Hasil uji t variabel bebas penempatan dan promosi jabatan terhadap variabel kinerja kerja karyawan PT. Gramedia Asri Media Kupang

\begin{tabular}{|l|l|l|l|}
\hline Model & t Tabel & t Hitung & Sig \\
\hline X1 & 1,660 &,- 465 &, 645 \\
\hline X2 & 1,660 & 12,048 &, 000 \\
\hline
\end{tabular}
Sumber : Data Olahan

Keterangan:

1) Untuk hipotesis yang mengatakan bahwa ada pengaruh variabel penempatan terhadap kinerja kerja karyawan dapat diterima karena nilai sig antara penempatan $\left(\mathrm{X}_{1}\right)$ dan Kinerja kerja karyawan (Y) sebesar 0,645 ini bermakna bahwa nilai sig < $\alpha$ atau $0,645<0,05$ artinya ada pengaruh yang signifikan antara penempatan $\left(\mathrm{X}_{1}\right)$ dan kinerja kerja karyawan (Y). Hal ini dapat dijelaskan bahwa jika semakin baik penempatan karyawan yang dilakukan maka akan meningkatkan kinerja kerja karyawan.

2) Untuk hipotesis yang mengatakan bahwa ada pengaruh promosi jabatan terhadap kinerja kerja karyawan dapat diterima karena nilai sig antara promosi jabatan $\left(\mathrm{X}_{2}\right)$ dan kinerja kerja karyawan (Y) sebesar 0,000 ini bermakna bahwa nilai sig $<\alpha$ atau $0,000<0,05$, artinya ada pengaruh yang signifikan antara promosi jabatan $\left(\mathrm{X}_{2}\right)$ dan kinerja kerja karyawan (Y). Hal ini dapat dijelaskan bahwa jika semakin baik strategi promosi jabatannya maka akan meningkatkan kinerja kerja karyawan.

\section{b. Uji hipotesis secara bersama-sama / simultan (uji F)}

Uji simultan ini bertujuan untuk mengetahui pengaruh secara simultan variabel penempatan dan promosi jabatan terhadap variabel kinerja kerja karyawan.

Hasil uji F pada tabel 4.13 menunjukkan nilai Sig sebesar 0,000 yang berarti nilai Sig $<\alpha$ Karena nilai Sig $<\alpha$ maka dapat disimpulkan bahwa secara bersama-sama variabel bebas penempatan (X1), promosi jabatan (X2) berpengaruh secara signifikan terhadap variabel terikat kinerja kerja karyawan (Y).

\section{Koefisien Determinasi $\left(R^{2}\right)$}

Koefisien determinasi digunakan untuk mengetahui sumbangan variabel bebas penempatan $\left(\mathrm{X}_{1}\right)$, promosi jabatan $\left(\mathrm{X}_{2}\right)$ terhadap variabel kinerja kerja karyawan (Y).

Hasil uji koefisien determinasi $\left(R^{2}\right)$ diperoleh besarnya R Square adalah 0,861 . Hal ini menyatakan $86,1 \%$ kinerja kerja karyawan dapat dijelaskan oleh variabel penempatan dan promosi jabatan, sedangkan sisanya 13,9\% dijelaskan oleh sebab-sebab lainnya, seperti motivasi kerja, disiplin kerja, kompensasi karyawan yang bisa menjadi penyumbang variabel kinerja kerja karyawan.

\section{PENUTUP}

\section{Kesimpulan}

Berdasarkan hasil penelitian dan pembahasan yang telah diuraikan pada bab sebelumnya, maka dapat ditarik kesimpulan sebagai berikut :

1. Berdasarkan deskripsi persepsi karyawan untuk variabel penempatan dan variabel promosi jabatan pada karyawan PT. Gramedia Asri Media Kupang selama tahun 2012 - 2016 memberikan pengaruh signifikan yang tergolong sedang/cukup yakni untuk variabel penempatan sebesar 54\% dan variabel promosi jabatan sebesar 
56\% terhadap variabel kinerja kerja Saran karyawan sebesar $60 \%$.

Untuk meningkatkan kinerja kerja

2. Pengujian untuk analisis regresi linear berganda dengan persamaan $\mathrm{Y}=1,216+$ $0,852 \mathrm{X} 1+0,343 \mathrm{X} 2$ yakni penempatan dan promosi jabatan berpengaruh terhadap kinerja kerja karyawan.

3. Berdasarkan hasil analisis pengujian hipotesis secara parsial dan simultan mempunyai pengaruh secara signifikan terhadap kinerja kerja karyawan.

4. Berdasarkan hasil analisis koefisien determinasi $\left(R^{2}\right)$, ditemukan bahwa 2 variabel bebas yang digunakan dalam penelitian ini memberikan sumbangan sebesar $86,1 \%$ dari kinerja kerja karyawan dan sisanya sebesar $13,9 \%$ dijelaskan oleh variabel-variabel lain yang tidak disertakan dalam penelitian ini.

karyawan pada PT. Gramedia Asri Media

Kupang, maka dibuat saran sbb:

1. Bagi PT. Gramedia Asri Media Kupang

Dalam melakukan proses penempatan diharapkan untuk memperhatikan unsurunsur tingkat pendidikan, pengetahuan kerja, ketrampilan kerja, dan pengelaman kerja juga di tahap promosi jabatan agar memperhatikan tentang aturan untuk penilaiannya secara efektif meliputi carring, credible, competent, competetive dan customer delight sehingga akan sangat berguna untuk meningkatkan kinerja kerja karyawannya.

2. Bagi Peneliti lain

Diharapakan dapat melakukan penelitian lanjutan untuk mengetahui unsur-unsur lain yang dapat mempengaruhi kinerja kerja karyawan pada PT. Gramedia Asri Media Kupang seperti motivasi kerja, kompensasi karyawan, tingkat kedisiplinan, gaya kepemimpinan, loyalitas kerja karyawan yang dapat mendukung hasil penelitian ini. 


\section{DAFTAR PUSTAKA}

Davis, Keith. 2004. Human Behavior At Work Organizational Behavior Sixth Edition. Tata McGraw-Hill Company Ltd. New Delhi

Drucker, Peter F. 2001. Managing For Results (Economic Tasks and Risk-Taking Decesions). Pan Books Ltd

Hasibuan, Malayu, S.P. SumberDayaManusia. Jakarta :BumiAksara, 2001

. (2007)Manajemen Personalia (Manajemen Sumber Daya Manusia). Jakarta:Ghalia Indonesia

. (2012) Strategi Terintegrasi dalam Perencanaan Sumber Daya Manusia Dalam Usmara,

A (ed), Paradigma Baru Manajemen Sumber Daya Manusia, Yogyakarta: Amara books

Hawawi,

KebijakankinerjaKaryawandankiatmembangunOrganisasiKompetitifMenjelangPerdagang anBebasDunia. Yogyakarta: BPFE, 2000

HeidjrachmandanHusnan, Saud, ManajemenPersonalia. Yogyakarta-BPFE 2002

Jackson, S.E., and Schuler. R. S. 2007. Human Resource Planning: Challenges for Industrial/Organization Psychologists. New York, West Publishing Company

Kuncoro, Mudrajad. (2003). Metode Riset untuk Bisnis dan Ekonomi Bagaimana Meneliti dan Menulis Tesis? Jakarta: Erlangga

Mangkunegara. 2001. Kepemimpinan Dalam Manajemen, Jakarta

Nasution. 2000. Manajemen Pembangunan Indonesia: Sebuah Pengantar dan Panduan. Elex Media Komputindo. Jakarta: Gramedia

PeraturanAkademik, Kupang: STIE Oemathonis, 2002

Purwanto. 2007. Manajemen Sumber Daya Manusia. Jakarta: Salemba Empat

Riduwan. (2013). Metode dan Teknik Menyusun Proposal Penelitian untukMahasiswa S-1, S-2 dan $S$-3. Bandung: Alfabeta.

( 2013). Metode dan Teknik Menyusun Tesis. Bandung: Alfabeta.

.2010. MetodedanTeknikMenyususnTesis. Bandung : Alfa Beta

Rivai, Veithzal. 2005. Manajemen Sumber Daya Manusia untuk Perusahaan. Jakarta: RajaGrafindo Persada.

Sastrohadiwiryo. 2002. Manajemen Sumber Daya Manusia, Edisi keenam, Jilid 1. Penerbit Erlangga: Jakarta

Siagian, Sondang P. ManajemenSumber DayaManusia. Jakarta: BumiAksara, 2008

.Dergibson dan Sugiarto. 2002. Metode Statistika Untuk Bisnis dan Ekonomi. Jakarta: Gramedia. 
2009. Paradigma Baru Manajemen Sumber Daya Manusia. Yogyakarta: Amara books.

Sugiyono, 2007.MetodePenelitianAdministrasi: DilengkapiDenganMetode $R \& D$, Bandung : Alfa Beta . MetodePenelitianBisnis, Cetakankesembilan. Bandung: Penerbit CV. Alfa Beta. 2007

Sudjana. (2009). Manajemen Sumber Daya Manusia, Edisi keenam, Jilid 1. Penerbit Erlangga: Jakarta

Surat Edaran untuk Keputusan KPI dengan nomor KPI/STD/GAM/02/2011, tentang Penilaian KPI (Key Perfomance Indicator) Kompas Gramedia

Soelaiman. 2007. Manajemen Sumber Daya Manusia. Bandung: CV. Alfabeta

Teguh Sulistiani, Ambar. 2003. Memahami Governance dalam Perspektif Sumber Daya Manusia. Yogyakarta: Gaya Media

Umar, Husein. (2002).Metode Riset Komunikasi Organisasi: Sebuah Pendekatan Kuantitatif Dilengkapi Dengan Contoh Proposal dan Hasil Riset Komunikasi Organisasi. Jakarta: Gramedia

Wantur. (skripsi 2008). "Pengaruh Program Kesejahteraan Terhadap Kinerja Karyawan pada Pusat Koperasi Unit Desa (PUSKUD) NTT."

Wahyudi. 2002. Manajemen Sumber Daya Manusia. Edisi kedua. Yogyakarta: Andi Offest 